\title{
Prioritering, profilering og politisk orientering Engagement og aktivisme i dansk udviklings- og bistandspolitik 1962-2015
}

\author{
Thorsten Borring Olesen \\ Professor, Institut for Kultur og Samfund, Aarhus Universitet
}

I de senere år har der været ført intense debatter om aktivisme i dansk udenrigspolitik. Denne debat har også inddraget udviklings- og bistandspolitikken, hvor det af og til hævdes, at der siden Fogh-Rasmussen regeringens tiltræden i 2001 er sket et paradigmeskift inden for tilrettelæggelsen af politikken på området. Spørgsmålet er dog komplekst, og med udgangspunkt i en analyse af udviklingspolitikkens prioritering, politiske orientering og internationale profilering i perioden 1962-2015 diskuterer artiklen kontinuitet og brud i den danske aktivisme på området og på basis heraf, om der er sket - eller er ved at ske - et paradigmeskifte i udviklings- og bistandspolitikken.

Da daværende udenrigsminister Per Hækkerup i 1965 lagde navn til bogen Danmarks udenrigspolitik, kanoniserede han en forståelse af udenrigspolitikken som spændt ud mellem fire hjørnesten: NATO, FN, Norden og Europa. Udlægningen var ikke Hækkerups egen originale. Det var en forståelse, der på denne tid var udbredt i Udenrigsministeriet, og allerede Hækkerups forgænger på posten, Jens Otto Krag, havde udlagt teksten på lignende vis, først med tre hovedelementer og senere - efter Danmarks første ansøgning om EEC-medlemskab i 1961 - som organiseret langs fire hovedlinjer, som var lig Hækkerups hjørnesten (Borring Olesen og Villaume 2005, s. 15 ff.).

En senere forskning har slået fast, at denne forståelse ikke kun var beskrivende, men til en vis grad også handlingsorienterende - og legitimerende baseret som den var på en funktionel kompartmentalisering (Due-Nielsen og Petersen 1995, s. 40) af udenrigspolitikkens forskellige elementer, som svarede til politikkens indholdsmæssige opdeling i de tre hovedkomponenter: 1) sikkerhedspolitik (NATO-hjørnestenen, og til dels FN-hjørnestenen); 2) udenrigsøkonomi/markedspolitikken Europa- og Norden-hjørnestenene), samt 3) idé- eller renommépolitikken (FN-hjørnestenen, og til dels Norden-hjørnestenen). Hjørnestenenes formelle uafhængighed, men reelle gensidige afhængighed, gav de skiftende regeringer nogle forskellige håndtag, når udenrigspolitikken skulle tilrettelægges. Krævede NATO-politikken indordning, kunne FN-politikken bruges til at mildne konsekvenserne af denne regimentering. På samme måde kunne det nordiske kort bringes i anvendelse, hvis Europa- eller markedspolitikken var kørt fast, enten ved at arbejde for Norden som alternativ til EF-medlemskab, eller - som det i stigende grad blev tilfældet - som en platform for mødet med EF.

Allerede denne korte introduktion antyder, at dansk udenrigspolitik i perioden før Murens fald langt fra kun tilpassede sig passivt til omgivelserne. Der var også hyppigt og i stigende grad fra 1960 'erne og frem tale om en mere aktivistisk politik, hvor beslutningstagerne arbejdede for danske undtagelser og forbehold, samtidig med at de prøvede at påvirke og ændre gældende internationale normer og vilkår. En vigtig ressort for den sidstnævnte bestræbelse blev et helt nyt politikfelt i efterkrigstidens udenrigspolitik, nemlig udviklings- eller bistandspolitikken, som er denne artikels genstandsområde. Især efter vedtagelsen af den første lov om Danmarks deltagelse i det internationale bistandssamarbejde, Lov om Teknisk Samarbejde med Udviklingslandene, fra 1962 blev dette område udviklet og udvidet som et element i dansk udenrigspolitik.

Med loven fik danske regeringer et håndtag, som i stigende blev brugt til at understøtte og udvikle den internationalistiske side af udenrigspolitikken, idet udvik- 
lingspolitikken samtidig både blev opfattet og fungerede som en støtte til FN-systemet. Samtidig er udviklingspolitikken med tiden blevet relativt højt prioriteret, hvilket bl.a. kan ses af, at Danmark siden slutningen af 1970'erne har været del af den lille håndfuld lande, som har levet op til FN's målsætning for de rige lande om årligt at yde mindst $0,7 \%$ af BNI i statslig udviklingsbistand. Såvel i de relevante internationale udviklingsfora som ude i 'bistandsmarken' har den danske udviklings- og bistandsengagement været præget af et aktivt engagement, og i tiåret efter Murens fald måske endda ligefrem et aktivistisk internationalistisk engagement.

Spørgsmålet er imidlertid om dette fortsat er tilfældet. I en del nyere forskning er det således opfattelsen, at der siden 'systemskiftet' i 2001, hvor Anders Fogh Rasmussen blev statsminister med støtte fra Dansk Folkeparti, er sket et brud eller i det mindste en markant forandring af såvel udenrigspolitikken som helhed som af udviklingsog bistandspolitikken mere særskilt. Problemet er dog komplekst, idet det ikke er helt indlysende at hævde, at vi har været vidne til et fuldtonet paradigmeskift. Svaret er nemlig ikke nødvendigvis det samme, hvis man kigger på elementerne "aktivisme“ og ,internationalisme“ individuelt, ligesom der gør der sig nogle særlige forhold gældende inden for udviklings- og bistandspolitikken. Disse særlige forhold betyder eksempelvis, at konklusioner om forandringer i den overordnede sikkerhedspolitiske orientering og konfigurering ikke automatisk kan overføres til udviklings- og bistandspolitikken, selv om netop relationen mellem de to dele af udenrigspolitikken er blevet tættere sammenkoblet også på det operationelle niveau efter 2001 og den erklærede kamp mod terror (om forskningspositionerne vedr. den generelle udenrigspolitik, se Gram-Skjoldager \& Brun Pedersen 2015; vedr. udviklings og bistandspolitik se Stepputat, Engberg-Pedersen $\&$ Fejerskov 2012 og Brunbech \& Borring Olesen 2013).

På denne bagrund er det hensigten med denne artikel at analysere brud og kontinuitet $\mathrm{i}$ engagement og aktivisme i den danske udviklings- og bistandspolitik. Det vil ske med udgangspunkt i de tre parametre, prioritering, politisk orientering og international profilering appliceret på politikken i perioden 1962 til i dag. Med prioritering menes, i hvor høj grad regering og det politiske system har afsat menneskelige og økonomiske ressourcer til udviklingspolitikken. Med politiske orientering henvises til hvilke roller og værdier, udviklingspolitikken tilskrives inden for den overordnede udenrigspolitik; og med profilering henvises til hvor meget siddende regeringer bruger udviklingspolitikken som redskab i sin internationale profilering, bl.a. ved at se på graden af egne, større politiske initiativer på området. Denne operationalisering gennemføres for at etablere en baggrund for nærmere at diskutere karakteren og graden af politisk aktivisme på feltet og herunder, om der er sket - eller er ved at ske et paradigmeskifte i dansk udviklingspolitik. Et sådant paradigmeskift må altså vurderes i relation til ændringer i såvel den udviklings- og bistandspolitiske orientering som i graden af aktivisme.

\section{Bistandspolitikkens etablering i dansk udenrigs- politik 1962-1991}

Bistandspolitikkens indtog i dansk udenrigspolitik skete for alvor med baggrund i den nævnte lov om teknisk bistand til udviklingslandene fra 1962 og lovens modernisering i 1971 i Lov om Internationalt Udviklingssamarbejde. Konsekvensen af moderniseringen var i høj grad, at den praksis, der havde udviklet sig i 'gründerårene' i 1960 'erne, nu blev skrevet ind i den nye lov. Som noget helt afgørende fastholdt man, at bistandsadministrationen hørte hjemme i Udenrigsministeriet, efter 1971 endda som en selvstændig afdeling under navnet $\mathrm{Da}$ nida, fra 1986 som eget departement (Jørgensen 1977; Brunbech 2006; Borring Olesen 2008a, 350 ff.). Denne placering indikerer, at danske politikere fra starten har set bistandspolitikken som en del af udenrigspolitikken, hvilket også falder logisk i tråd med 1971-lovens formålsbeskrivelse om i samarbejde med u-landene at understøtte dem i „deres bestræbelser på at opnå økonomisk vækst for derigennem at medvirke til sikring af deres sociale fremgang og politiske uafhængighed [...]" (citeret efter Pedersen 2008, 121).

Den statslige danske bistandspolitik blev ikke født i 1962. Den havde rod tilbage til 1940 'erne, hvor Danmark efter krigen ydede nødhjælp til en række lande og til USA's og FN's første forsøg på at etablere multilaterale hjælpeprogrammer. Men når Danmark fik sin første bistandslov og sine første egentlige bilaterale hjælpeprogrammer i 1960'erne, hang det i høj grad sammen med to overordnede, internationale udviklingstræk, nemlig den kolde krig og afkolonialiseringsprocessen. USA's rolle som leder af Vestblokken var i stigende grad ved at blive en $ø$ konomisk belastning. De militære udgifter var massive, og det var de politisk-økonomiske omkostninger for at opretholde indflydelse i de nye stater i Den Tredje Verden også. USA opfordrede derfor sine allierede til $i$ at indgå i en stigende grad af 'burden sharing' i forhold til koldkrigens udgifter. Med oprettelsen af OECD og dens underkomité, udviklingskomitéen DAC, i begyndelsen af 1960'erne blev der skabt en ramme for en højere grad af politisk-økonomisk byrdefordeling i forhold til de nye Syd-lande (Holm 1982, 25 f.; Brunbech 2006, Pedersen 2008, 130 ff.).

For de danske beslutningstagere blev det nye internationale fokus på udviklingspolitik en chance for at indlemme et instrument i udenrigspolitikken, der var skræd- 
dersyet til den nye globale kontekst, som både den kolde krig og afkolonialiseringen havde skabt. Det var ikke en ualmindelig opfattelse i deténte-tiden i 1960erne, at Nord-Sydproblemet, forstået som uligheden i verden, på længere sigt kunne blive vigtigere for verdens sikkerhed end Øst-Vestproblemet. Det var også et synspunkt, Per Hækkerup luftede i sin bog fra 1965. Samtidig havde en satsning på bistandspolitik som 'burden sharing' tre klare fordele. For det første kunne en større indsats her være en belejlig afværge, når Danmark af sine allierede blev kritiseret - og det skete jævnligt - for at underpræstere på sit militære bidrag. For det andet var bistandspolitikken som skræddersyet til at styrke det internationalistiske element, herunder FN-elementet, i dansk udenrigspolitik - en bestræbelse som generelt blev stærkt opprioriteret i 1960'erne og 70'erne.

Endelig for det tredje udstyrede bistandspolitikken både i sin multilaterale og sin nye bilaterale skikkelse det danske diplomatiske instrumentarium med nogle nye globale redskaber i dele af verden, der blev stadig vigtigere, men hvor Danmark ingen tradition havde for at være til stede (Borring Olesen \& Villaume 2005, 374 ff.; Brunbech \& Borring Olesen 2013, 114 f.). Denne udvikling pejlede således i sig selv en generel nyorientering i efterkrigstidens danske udenrigspolitik, nemlig behovet for en stærkere global orientering. Som udenrigsminister Jens Otto Krag slog fast i en tale i 1959: „Alt i verden kommer os ved“ (Krag 1959). Sådan ville ingen dansk politiker have udtrykt sig i perioden før 1945.

Alligevel kom det 'udviklingspolitiske turn' i 1960 'erne i nogen grad bag på danske politikere. Forestillingen var nemlig, at Danmark via sine forholdsvise høje bidrag til FN's multilaterale programmer allerede gjorde sin del. Men da OECD og DAC begyndte at måle landenes samlede bistand, både den multilaterale og den bilaterale, og sætte den i relation til BNP/BNI, havde Danmark ikke meget at bryste sig af. Faktisk lå den danske statslige bistandsprocent (meget lig den norske og den svenske) helt nede på omkring 0,1\% af BNI i perioden 1960-64, mens gennemsnittet for DAC-landene som helhed lå på omkring $0,5 \%$. Det var i øvrigt heller ikke så meget J.O. Krag selv som hans partifæller, statsminister Viggo Kampmann og udenrigsminister Per Hækkerup, som sammen en stor underskov af ngo'ere og politiske ungdomsbevægelser - gjorde sig til 'champions' for den tidlige bistandssatsning (Brunbech \& Borring Olesen, 2013, 89 ff; Bøgh 2003, 206 ff; Kelm-Hansen 2000, 37 ff).

Med erkendelsen af det ringe økonomiske bidrag fulgte til gengæld en klar opprioritering af området i årene derefter. FN havde ved udnævnelsen af 1960'erne til udviklingstiår anbefalet, at de rige medlemslande søgte at leve op til en målsætning om at sikre økono- miske overførsler (private og offentlige) i et omfang, der årligt svarede til 1\% af BNI. Den målsætning blev i 1970 ændret af FN til målsætningen om at overføre statslig bistandshjælp (ODA) på minimum 0,7\% af BNP. Under alle omstændigheder steg den danske bistandsprocent markant og kontinuerligt og nåede det anbefalede mål på 0,7\% i 1978 - som det fjerde land i verden efter Holland, Sverige og Norge. Frem til 2000 (hvor Luxembourg også tilsluttede sig gruppen) var disse fire såkaldte 'frontløber'lande' de eneste, som vedvarende og systematisk levede op til normen. Frontløberne gik endda skridtet videre og blev ved at øge bistanden, så den for Danmarks vedkommende ved afslutningen af den kolde krig var nået op i omegnen af 0,9\% af BNP (Ekengren \& Götz 2013; Brunbech og Borring Olesen 2013).

Tallene taler altså deres eget tydelige sprog om, at området i stigende grad blev prioriteret og set i en international sammenhæng stærkt prioriteret. På den anden side vedblev det i denne periode at være sådan, at udviklings- og bistandspolitikken aldrig fik sin egen minister eller ministerium. Kulturminister Kristen Helveg Pedersen havde i VKR-perioden området under sin portefølje, ligesom Lise Østergaard, der i en periode var Minister uden Portefølje (1977-1980) under Anker Jørgensen, varetog en række udviklings- og bistandspolitiske opgaver. Denne struktur antyder således, at der var grænser for, hvor vigtig de danske regeringer anså området for at være, ligesom det også er helt oplagt, at det stadig var de økonomiske og politiske afdelinger i Udenrigsministeriet, der var sværvægterne, og som agerede øverste instans, når bistandsspørgsmål tørnede sammen med andre udenrigspolitiske hensyn. Det skete eksempelvis ikke sjældent inden for finans- og handelsspørgsmål.

Hvad man kan slå fast er, at bistandsfeltet i perioden 1962-1991 voksede i betydning og omfang, som både fremgår af bistandsbevillingerne i sig selv, men også af Danidas personalemæssige store ekspansion med mere end en fordobling af medarbejderstaben fra 1971 til 1990. Det fremgår også af den nævnte ophøjelse af Danida til et ligeberettiget departement i 1986 på linje med de to 'klassiske' departementer for udenrigsanliggender og udenrigsøkonomi. Ligeberettigelsen afspejlede, at udviklingspolitikken var vokset ud af de øvrige udenrigsministerielle politikområders skygge som et selvstændigt og prioriteret element i udenrigspolitikken. Den traditionelle sikkerhedspolitik og udenrigsøkonomiske politik blev fortsat på regeringsplan opfattet som mere vital for varetagelsen af Danmarks nationale interesser, men udviklingspolitikken kunne og blev ikke længere opfattet som et isoleret appendiks til de vigtige sider af udenrigspolitikken (Borring Olesen 2008a, 350 ff.) 
Når det var tilfældet, skyldes det som nævnt ikke mindst, at bistandspolitikken blev et vigtigt element i FNhjørnestenen og dermed i den internationalistiske komponent i dansk udenrigspolitik. Som bl.a. Hans Branner og Kristine Midtgaard har argumenteret, var dansk udenrigspolitik under den kolde krig spændt ud mellem 'realistiske' korttidstilpasninger (NATO) og en mere langsigtet, idealistisk internationalistisk målsætning (Branner 2000; Midtgaard, 2005, 358-375). Især under 1960'ernes og 70'ernes Øst-Vest afspændingsperiode kom sidstnævnte dimension langt klarere til udtryk i dansk udenrigspolitik, som også resulterede i en stærkere aktivistisk profil. Profilen blev hævet henover alle fire hovedhjørnesten, men mest systematisk og kontinuerligt inden for FN-hjørnestenen, og hvor netop opdyrkelsen af det bistandspolitiske felt kan ses som et udtryk for dette. Det forklarer også, hvorfor den multilaterale komponent i den danske bistand forblev meget høj. Målsætningen hed en fifty-fifty fordeling mellem bilateral og multilateral bistand, som den multilaterale del med tiden måske ikke helt kom til at matche, men den var tæt på. Den bærende logik bag denne prioritering udtrykte Lise Østergaard ganske klart ved i 1977 at slå fast, at det "ganske klart (er) en småstatsinteresse, som motiverer os for at yde relativt mere via FN’s særorganisationer" (Borring Olesen 2008a, 339).

Man kan i det hele taget tale om, at bistandspolitikken sammen med FN-politikken og den bilaterale håndtering af relationerne til landene i Den Tredje Verden indgik i et samlet Syd-diplomati, der på visse områder var særdeles aktivt og profileret. Det var stærkest i 1960'erne og 70'erne, men gjorde sig også gældende i 1980'erne, selv om såvel den internationale kontekst (den nye skærpelse af den kolde krig og en stærkere neo-liberal konditionalitetsapproach til bistand) og den nationale kontekst (borgerlig udenrigspolitik med Schlüter og Ellemann under det alternative flertals vilkår) her dæmpede aktivismen.

Konkrete eksemplet på aktivismen finder man på afkolonialiserings- og apartheidspørgsmålene i FN og i det danske Afrikadiplomati. Her lagde Danmark sig ved flere lejligheder ud med NATO-allierede som Portugal, Vesttyskland, Frankrig og Storbritannien, når man promoverede eller støttede resolutioner vendt mod kolonialisme og apartheid. Et konkret eksempel er den danske støtte i november 1976 til en FN-resolution om våbenembargo mod Sydafrika, hvor teksten direkte kritiserede Vesttyskland, Frankrig og Storbritannien for deres engagementer med Sydafrika. Her fik den danske regering efterfølgende hård kritik, bl.a. også fordi Danmark på den måde brød med solidariteten i det europæiske politiske samarbejde (EPS). Senere i 1986 bar det alternative flertal mod Schlüterregeringens ønsker en beslutning igennem Folketinget om, at Danmark - som det første land - implementerede en fuld handelsboykot mod apartheidstyret (Midtgaard 2009; Petersen 2006, 104 ff; Borring Olesen 2008a, 341).

Det er bl.a. sådanne prioriteringer, der er baggrunden for Nikolaj Petersens vurdering i bd. 6 af Dansk Udenrigspolitiks Historie, at Afrika var det felt, „hvor dansk udenrigspolitik i 1970'erne fik sin mest selvstændige profil“ (Petersen 2006, 141). Profilen blev som vist plejet i FN, men også gennem et omfattende bilateralt diplomati, der både inddrog statsledere og repræsentanter for de oprørsbevægelser, der bekæmpede kolonialisme og apartheid, og hvor ikke mindst udenrigsminister K.B. Andersen var en central aktør. Afrikapolitikken førte også indimellem til uoverensstemmelser med USA, når Danmark sammen med de øvrige nordiske lande anerkendte og bistandsunderstøttede venstreorienterede/marxistiske oprørsbevægelser og efterfølgende regeringer i lande som Angola, Mozambique og Namibia. Mest kontroversiel i Danmark var den øremærkede støtte til afrikanske befrielsesbevægelser, som Krag-regeringen indførte i 1972 som supplement til den særlige apartheid-bevilling introduceret i midten af 1960'erne. Mere generelt var det også i overensstemmelse med prioriteringen, når Afrika modtog en overordentlig stor del af de danske bistandsmidler i denne periode med Tanzania som største enkeltmodtager. (K.B. Andersen 1983, 14-51; Petersen 2006, 141 ff; Borring Olesen 2008a, $340 \mathrm{ff}$.)

Denne brug af bistandsmidler understøtter tolkningen af, at bistand blev opfattet som et virkemiddel i den bredere danske udenrigspolitik, hvilket Danida også åbent erkendte, bl.a. i sin handlingsplan fra 1988, hvor det hed, at den såkaldte SADCC bistand til landene i det sydlige Afrika måtte ses som et supplement til den danske politik mod apartheid (Borring Olesen 2008a, 341). Samtidig er det imidlertid også interessant, at der bag rationalet for en del af den danske bistand gemte sig et koldkrigshensyn. Når danske regeringer anerkendte og støttede venstreorienterede bevægelser og regeringer i Afrika, var det også, fordi man ønskede at opstille et alternativ til den gunst, Østblokken overøste dem med. Det var i øvrigt dette perspektiv, der gav anledning til uoverensstemmelser med USA, idet amerikanske regeringer hellere så 'regime change' som forudsætning for anerkendelse og hjælp end anerkendelse og hjælp som midler til kontakt og langsigtet forandring.

Umiddelbart kunne det også se ud, som om den danske politik forsøgte at harmonisere to uforenelige hensyn i sin politik, nemlig et realistisk koldkrigshensyn og et internationalismehensyn. Men i de danske regeringers forstålse var der ikke tale om nogen logisk modsætning, da internationalismeforståelsen hvilede på en forudsætning om, at internationalismen på den ene side kun skulle efterstræbes, hvis politisk frihed kunne sikres, og på den 
anden side kun kunne realiseres på basis af en stabil magtbalance. På den måde var der ikke kun tale om funktionel afgrænsning mellem de danske hjørnestene, men også om politisk interdependens (Midtgaard 2005, 334-357).

Det, man derimod kan diskutere, er balancen i den danske politik. Ovenfor er der argumenteret for, at det danske Syd-diplomati fra 1960'erne til 1980'erne, men med mest prægnans i 60'erne og 70'erne, havde en markeret og stærk profil båret frem af en internationalistisk forståelse og ambition. Men det er ikke hele historien. Perioden byder også på en hel del eksempler, hvor danske regeringer i Syd-diplomatiet var mere tilbageholdende og lavprofilerede. Et meget markant eksempel er den danske profil i 1970'ernes omfattende debat i FN og dens underorganisationer om u-landenes krav om en Ny Økonomisk Verdensorden (NØV).

NØV-intermezzoet er ikke mindst interessant, fordi det er et af de få eksempler under den kolde krig på, at udviklingslandene formåede at sætte en international dagsorden. Set fra Vesten var den imidlertid yderst radi$\mathrm{kal}$ med sine fordringer om bl.a. råvarefonde, nationaliseringer og teknologideling samt ændring af styreformerne i globale økonomske institutioner som Verdensbanken og Valutafonden. I disse debatter havde Norge og Sverige en stærkere profil end Danmark, som både var forbeholden over for at love penge til råvarefondene og til politisk at binde sig alt for stærkt til NØV-principperne. Det blev også internationalt bemærket, idet en Verdensbankanalyse fra 1976 rubricerede den danske holdning til råvarefond-spørgsmålet som liggende $\mathrm{i}$ en midterposition sammen med lande som Belgien, Irland og Italien.

Modstanden mod råvarefondene og andre af $\mathrm{N} \varnothing \mathrm{V}-$ kravene demonstrerer naturligvis ikke i sig selv, at de danske regeringer havde et lavt engagement. Selv i en internationalisme-optik kunne der være rimelige grunde til at afvise de konkrete forslag, men for et land, der på det mere generelle plan støttede ambitionen om en mere retfærdig verdensorden, var det påfaldende, at det primære danske bidrag til NØV-diskussionerne begrænsede sig til en vedvarende opfordring til, at Nord-Syddialogen ikke måtte opgives (Borring Olesen 2008b).

I DAC-sammenhæng så man også ofte Danmark indtage en mere moderat position end fx Sverige. Danske regeringer lagde mere vægt på at opnå kompromisser, som også USA kunne tilslutte sig. Denne forskel i dansk-svensk tilgang vil være oplagt at udlægge som en konsekvens af deres forskellige status som allieret versus neutral, men det spillede også ind på holdningen, at danske regeringer anså det for vitalt at fastholde USA som aktiv spiller inden for det internationale bistandsregime, som havde udviklet sig siden 1960'erne. Denne holdning gav i øvrigt også danske regeringer pondus til at tage den profilerede kritikerhat på over for USA og andre Vestallierede, når de ikke gjorde seriøse forsøg på at leve op til målsætningen om årligt at give $0,7 \%$ af BNP i statslig bistand. Her var danske regeringer ofte yderst profileret i kritikken, både når de optrådte selvstændigt i DAC eller sammen med den nordiske gruppe i Verdensbanken (Borring Olesen 2008a, 278 ff. Og 307 ff.).

Opsamlende om perioden 1962-1991 må man konstatere, at bistandspolitikken var lavt prioriteret ved indgangen til perioden, men højt prioriteret ved udgangen både politisk og ikke mindst økonomisk med en stigning i de årlige ODA-overførsler fra omkring 0,1\% til 0,9\% af BNP. Politisk blev bistandspolitikken en mere selvstændig og supplerende del af udenrigspolitikken, bl.a. som et centralt understøttende element i et aktivistisk Syd-diplomati knyttet til internationalisme-perspektivet i FN-hjørnestenen. I komparativ sammenhæng var den danske aktivisme på feltet dog ofte mindre profileret end Norges og Sveriges, mens prioriteringen forstået som det relative antal bistandsmidler afsat på feltet var ganske sammenligneligt. Man kan til gengæld tilføje, at den danske politik måske var en anelse mere troværdig, idet afstanden mellem, hvad man lovede, og hvad man leverede, nok var mindre end i det norsk-svenske tilfælde.

\section{Danmark som bistandspolitisk 'front runner' 1991-2001}

Med Murens fald var der i mange u-landskredse en forventning om udbetalingen af en fredsdividende, når Øst-Vest-konflikten forventeligt ikke længere ville lægge beslag på så mange ressourcer. U-landene opdagede imidlertid snart, som Christian Friis Bach har udtrykt det, at der ikke ville blive tale om nogen fredsdividende, men derimod om et tab af koldkrigsdividenden (Friis Bach 2008, 404). Med fraværet af den bipolære kappestrid tabte de rige donorlande noget af motivationen for at kanalisere bistand til udviklingslandene, mens især en række vesteuropæiske lande øgede bistanden til det østeuropæiske område. Hvor DAC-landenes samlede ODA/ GNI bidrag i år 1990 stod på 0,32\%, var det ti år senere i 2000 faldet til 0,22\% (OECD.StatExtracts: total flows by donor (ODA\%GNI)).

Til gengæld vendte en stor del af de private overførsler og investeringer, som var faldet drastisk i 1980'erne, igen tilbage. Dette var i sig selv med til at pejle et nyt fokus i Nord-Sydforholdet, nemlig en forskydning fra 'aid to trade' herunder private investeringer og markedsøkonomi. Symbolsk kom det udtryk ved oprettelsen af den nye globale handelsorganisation WTO i 1995, som samtidig betød, at FN's Syd-dominerede handelsorganisation UNCTAD kom til at leve en hensygnende tilværelse. 
Overordnet set var dette ikke en dårlig udvikling. Det repræsenterede faktisk en tilbagevenden til det slogan, udviklingslandene selv havde betjent sig af under NØV-debatterne i 1970'erne, „Trade, not Aid“. Problemer var bare, at WTO handelsregimet blev noget anderledes indrettet, end det u-landene oprindeligt havde stræbt efter med en tendens til, at de stigende private overførselsstrømme snarere gik til 'the speedy' end til 'the needy', altså ikke til de fattigste og mindst dynamiske lande. Den danske bistand trak imidlertid i modsat retning. Ikke nok blev den ved med at stige. Den vedblev også med at have en markant fattigdomsorientering, selv om den danske bistand også blev mere både konditionaliseret og markedsøkonomiseret (Friis Bach 2008, 393-413; Borring Olesen 2008b).

I 1992 nåede den danske bistand for første gang op på $1 \%$ af BNI, sådan som det var blevet vedtaget som målsætning - af det alternative flertal - i 1985. 90'erne igennem lå den danske ODA-procent på dette niveau, hvilket i anden halvdel af 1990 'erne gjorde Danmark til det land i verden, der målt på ODA/GNI-ratioen gav mest statslig bistand. Dette skal oven i købet ses i lyset af, at Nyrup Rasmussen-regeringen med miljøminister Svend Auken som meget aktiv pådriver etablerede den nye såkaldte MIKA bistandsramme øremærket til miljø og katastrofebistand, fra 1999 under forkortelsen MIFRESTA ændret til en miljø og freds- og stabilitetsramme. Rammerne betød, at Danmark faktisk kom meget tæt på at bruge 1,5\% af GNI årligt på udenlandsk bistand (OECD.StatExtracts: total flows by donor (ODA\%GNI); Lancaster 2007, 196; Friis Bach 2008, 398 ff.).

Selv om der også indimellem var tale om kreativ bogføring inden for udviklingshjælpen - inden for de rammer som DAC accepterede - bl.a. ved at bruge udviklingsmidler på modtagelsen af de mange Balkanflygtninge, der i 1990'erne kom til Danmark, vidner tallene om, at prioriteringen af bistandshjælp aldrig havde været større. Prioriteringen kom også til udtryk ved, at Nyrup Rasmussen regeringerne nu for første gang udpegede en egentlig udviklingsminister, som i perioden blev beklædt af Helle Degn, Poul Nielson, Jan Trøjborg og Anita Bay Bundegaard. Det tunge kort her i rækken var Poul Nielson, som sad på posten i fem år (1994-1999), inden han flyttede videre til Bruxelles og blev EU kommissær for udvikling - hvilket i sig selv kan ses som et resultat af den danske prioritering af området.

Prioriteringen kan også delvis aflæses af den nye organisering af Udenrigsministeriet, som blev indført i 1991. Fra 1. maj dette år blev ministeriet indrettet som enhedsorganisation med to afdelinger benævnt henholdsvis Nord- og Syd-gruppen. Danida videreførtes som anker for alt, hvad der havde med udviklingsbistand at gøre og blev derfor en meget central aktør i Syd-gruppen, fordi næsten alle lande i Syd var udviklingslande. Med den nye organisering blev der også skabt en stærkere organisatorisk og dermed integreret sammenhæng mellem bistandssamarbejdet og de politiske, økonomiske og handelsmæssige sider af dansk udenrigspolitik, som også blev implementeret 'i marken' rundt omkring på ambassaderne (Danida 1991, 157 f.; Petersen 2006, 431 ff.). På den ene side var der med denne organisering skabt mulighed for en endnu højere grad af integration af bistanden $i$ den generelle udenrigspolitik, men på den anden side blev der også skabt rammer for en højere grad af kobling med andre hensyn, $\mathrm{fx}$ handelsmæssige, til bistandspolitikken og bistandsprojekterne.

I det hele taget kan man sige, at den nye organisering også afspejlede, at den traditionelle hjørnestenskonceptualisering af dansk udenrigspolitik ikke længere var gældende hverken i teori eller praksis. Den nordiske hjørnesten var siden 1980 'erne skrumpet stærkt, mens den europæiske var tilsvarende styrket, og sikkerhedspolitikken var ikke længere funktionelt kompartmentaliseret mellem NATO-søjlen og FN-søjlen. Efter Murens fald og det medfølgende fravær af en egentlig territoriel trussel mod det danske nærområde kunne begge søjler forenes i en fælles dimension rettet mod at styrke internationalismen $\mathrm{i}$ den danske politik. I den forstand skabte Murens fald et 'window of opportunity', som såvel Schlüter-regeringen som Nyrup Rasmussen-regeringerne aktivt forfulgte. Det aktivistiske element var højt og blev forfulgt helt ud på det militære plan med engagementerne i Golfen og på Balkan. Selv om Danmark også havde haft en haft en ganske høj profil i FN’s fredsbevarende missioner under den kolde krig, var den militære aktivisme, der nu også inddrog fredsskabelse, af en langt mere grundlæggende karakter (Petersen 2010, 348 ff; Wivel 2013, 309 ff.).

Men aktivismen blev også styrket på det bistandspolitiske felt. I sin første udenrigspolitiske redegørelse, som den nytiltrådte Nyrup Rasmussen regering præsenterede i 1993, slog man fast som erklæret mål at ville integrere bistandspolitikken endnu kraftigere i den generelle udenrigspolitik. Kodeordene hed satsninger på fælles sikkerhed, demokrati og menneskerettigheder, økonomisk og social udvikling samt miljø, hvilket også fandt markant nedslag i den nye bistandsstrategi, der året efter blev præsenteret under navnet En verden $i$ udvikling - eller bare Strategi 2000. Som resultat af strategien oprettede regeringen endvidere et Internationalt Humanitært Beredskab, der skulle stå for at udsende civile eksperter til humanitære, konfliktforebyggende eller fredsbevarende opgaver. Som Nikolaj Petersen har anført var der tale om en art pendant til den militære Internationale Brigade, der var under opstilling (Danida 1994; Olsen 2005, 193 ff; Petersen 2006, 558 ff.). 
Hvad udviklingsbistanden angår, fastholdt strategien fattigdomsorientering som bærende målsætning for den danske bistand. Men alle de andre hensyn i relation til demokrati, menneskerettigheder, bæredygtig udvikling, kvindehensyn m.m. nødvendiggjorde en betydelig mere aktiv styring af bistanden, som også lå i selve det faktum, at en stigende del af bistandshjælpen blev givet som programhjælp i stedet for til konkrete bistandsprojekter. Der krævede en mere intensiv dialog med modtagerlandene - en dialog som efterhånden antog konditionalitetslignende træk i takt med, at kravet om 'good governance' for alvor slog igennem i slutningen af 1990'erne som kriterium for bistandshjælp (Friis Bach 2008, 423-453).

På den konto kom det tydeligere bistandspolitiske kropssprog til at betyde, at Danmark ophørte med at have lande som Kenya, Malawi, Eritrea og Zimbabwe som programsamarbejdslande, ligesom man af mere overordnede politiske grunde fastfrøs bistanden til Indien, da landet i 1998 gennemførte en række atomprøvesprængninger, Bistandssamarbejdet med Indien kom aldrig i gang igen som tidligere, inden den indiske regering selv i 2003 meddelte, at den ville udfase bistanden fra Danmark og en række andre mindre donorer og oven i købet betalte restdelen på sit statslån tilbage. Indien ville tydeligvis ikke længere indgå i et samarbejde, hvor man skulle acceptere politiske krav for at modtage bistand (Friis Bach 2008, 429 ff.).

Aktivismen og den kravsorienterede tilgang kom ligeledes til udtryk i den multilaterale side af bistandspolitikken. I Strategi 2000 var det blevet slået fast, at Danmark ville tilstræbe en „aktiv multilateralisme“, som på den ene side indebar en fortsat stærk opbakning til 'fifty-fifty'bestræbelsen i den danske bistand (som blev nogenlunde efterlevet i praksis med en ca. 45-55\%'s fordeling mellem den multi- og bilaterale bistand i 1990'erne), og på den anden side resulterede i mere markante krav til de internationale bistandsorganisationer om, at de ligeledes praktiserede 'good governance' og samtidig havde blik for at ansætte danskere i organisationerne samt lægge indkøb i Danmark. Det blev i øvrigt også lettere at satse på de danske mærkesager, end det havde været i 1980'erne, fordi Verdensbanken nu også igen begyndte at prioritere fattigdomsbekæmpelse højere. Den største succes på feltet var nok, at det i 1995 lykkedes at få placeret FN's stort anlagte sociale topmøde med deltagelse af 118 stats- og regeringsledere i København (Olsen 2005, 193 ff.; Petersen 2006, $558 \mathrm{ff}$.).

Det lange årti fra Murens fald til 9/11 var en periode præget af uhørt dansk aktivisme på det bistandspolitiske felt. Man kan se det i prioriteringen, hvor Danmark gik mod den internationale strøm ved at lade bistanden stige, også relativt. Men man kan også se det i profileringen, hvor den danske politik både i den bilaterale del og den multilaterale del var meget synlig og engageret. Det passede med engagementet i den øvrige udenrigspolitik, og det passede ind med den overordnede internationalisme, der animerede udenrigspolitikken. Man må også slå fast, at de internationale politiske konjunkturer længe virkede befordrende for satsningen på en aktiv internationalisme og på at gøre bistandspolitikken til et redskab heri. Derimod må man også konstatere, at da de politiske konjunkturer begyndte at vende hen imod årtusindskiftet, både internationalt og nationalt, kom internationalismen og med den også bistandspolitikken under pres.

\section{Bistand i civil-militære rammer 2001-2015}

2001 blev et afgørende år for dansk bistandspolitik. 9/11-angrebene skabte en hel ny international dagsorden, og Fogh Rasmussen-regeringens tiltræden senere samme år gjorde i noget omfang det samme på det nationale plan, ikke mindst i relation til det bistandspolitiske felt. Afgørende her var, at regeringsdannelsen i $2001 \mathrm{kom}$ til at bryde med den parlamentariske tradition, ifølge hvilken flertal blev skabt henover midten i dansk politik. Denne tradition har haft en dynamisk indvirkning på bistandspolitikken, fordi de små midterparter, fra Det Radikale Venstre til CD og Kristeligt Folkeparti, generelt har været tilhængere af en stærk bistandspolitik. Det ændrede sig imidlertid, da Dansk Folkeparti (DF) trådte ind som parlamentarisk koalitionspartnere for Fogh Rasmussens VKregering. DF var stærkt kritisk over for den store danske udviklingshjælp og ønskede i stedet at bruge flere penge på nationalt velfærd - en ambition Fogh Rasmussen selv var lydhør overfor (Engberg-Pedersen 2007; Brunbech \& Borring Olesen 2013, 108 ff.).

Konsekvensen blev, at dansk bistand nu for første gang siden vedtagelsen af den første bistandslov i 1962 kom til at opleve et større fald både relativt og nominelt. I Nyrup Rasmussens sidste år (2001) lå udviklingsbistanden på 1,03 af BNI, hvad der svarede til en bistand på ca. 13,6 mia. kr., men to år senere i 2003 var udviklingsbistandsprocenten barberet ned til 0,84 og til ca. 11,5 mia. kr. nominelt. Samtidig blev MIFRESTA- rammen helt nedlagt. Med andre ord var det tale om en betydelig beskæring af bistanden, selv om bistandsprocenten aldrig i de følgende år kom under 0,8 og dermed heller ikke under FN-anbefalingen på de 0,7\% (OECD.StatExtracts: total flows by donor (ODA\%GNI).

Men som i 1990'erne var den danske udvikling i utakt med de internationale udvikling. Således steg den gennemsnitlige ODA/GNI procent for DAC-landene som helhed fra 0,21 til 0,31 fra 2001 til 2011. Med de såkaldte Millennium Development Goals fra 2000 havde FN sat fokus på udryddelse af fattigdom frem mod 2015 - en ambition EU ligeledes fulgte op på med strategier om vækst 
i EU-landenes ODA-bidrag (Riddle 2007, 40 ff.; Borring Olesen, Pharo \& Paaskesen 2013, 342 ff.). Endelig blev udviklings- og humanitær bistand i stigende grad også inkorporeret som værktøjer i den internationale kamp mod terror eller til stabilisering af skrøbelige stater. Denne udvikling førte endda til, at DAC flere gange fra årtusindskiftet og frem modificerede sine regler for, hvad der kunne indberettes som ODA, fx. ved at tillade registreringen af udgifter til civil og demokratisk kontrol med modtagerlandes sikkerhedssystemer, civil freds- og konfliktforebyggelse, reintegration af soldater og våben i en postkonfliktsituation m.m. som ODA (Friis Bach 2008, 438 f.; Stepputat, Engberg-Pedersen \& Fejerskov 2012, 43 ff.).

Den internationale udvikling kom også til at farve den danske tilgang til bistandspolitikken. Som vist var bistandspolitikken i 1990'erne blevet meget mere direkte integreret $\mathrm{i}$ udenrigspolitikken, og med MIFRESTArammen skabtes en mulighed for at binde civil-militære aktiviteter sammen, når det handlede om at stabilisere sikkerhedsudviklingen i skrøbelige eller fejlslagne stater. Men selv om udviklingsbistanden også havde en sikkerhedspolitisk kerne, forblev den grundlæggende et instrument øremærket til den langsigtede økonomiske, sociale, kulturelle og teknologiske kapacitetsopbygning og udvikling i de fattigste lande. Det ændrede sig imidlertid fra 2001 og især med danske krigsdeltagelse i Irak og Afghanistan. Med disse militære engagementer blev udviklings- og bistandspolitikken nu også intimt forbundet med sikkerhedspolitikken og med et direkte dansk militært engagement $i$ udviklingslande.

I regeringens bud for nye prioriteter for dansk udviklingsbistand for perioden 2004-08 læser man således, ,at udviklingspolitikken er en central og integreret del af dansk udenrigs- og sikkerhedspolitik" samt mere konkret, at regereingen vil „væsentligt opprioritere arbejdet med forebyggelse af konflikter, stabilisering og konsolidering af fred, såvel bilateralt som multilateralt. Udviklingsbistandens bidrag til kampen for stabilitet og sikkerhed og mod terrorisme vil blive fokuseret på konfliktforebyggelse, mægling, fredsskabende og bevarende indsatser og på indsatser til imødegåelse af international terrorisme og religiøs intolerance.“ (Danida 2003, 1 og 7 f.). Penge skulle der også afsættes til indsatsen med en stigning over perioden på 425 mill. dkk, samtidig med at regeringen også ville øge bevillingerne til nødhjælp og flygtninge med 860 millioner og til menneskerettigheder, demokratisering og god regeringsførelse med 500 mill kr. over de næste fem år.

Disse prioriteringer gik også hånd $\mathrm{i}$ hånd med en række diplomatiske mellemøstinitiativer, som udenrigsminister Per Stig Møller lancerede både med henblik på at promovere menneskerettigheder og god regeringsførelse i de arabiske lande og i et forsøg på gennem en 'roadmap' at få gang i fredsprocessen mellem Israel og dets naboer. Disse initiativer blev dog endegyldigt vingeskudt som følge af Mohammed-krisen i 2006, hvor Danmark ifølge en rapport fra Udenrigsministeriet havde lidt et imagetab i den muslimske verden og nu blev associeret til at være en del af det USA-ledede Vesten, „som opfattes som kynisk og dobbeltmoralsk" (Petersen 2006, 624 ff.).

Krisen kom således til at demonstrere for en hel verden, hvor vanskeligt det var for en småstat som Danmark at føre en aktivistisk, værdibaseret udenrigspolitik, og hvor begrænsende det kunne være for bistandspolitikken, hvis den bliver for tæe forbundet med mere direkte politiske og sikkerhedspolitiske prioriteringer. Det var Afghanistan et andet typisk eksempel på. Afghanistan havde ellers aldrig hørt til de store modtagere af dansk bistandshjælp, men den danske krigsindsats i Helmand ændrede på det, så Afghanistan i 2009 med 456 mill. kr. i udviklingsbistand kom til at høre til i toppen blandt modtagere af dansk udviklingshjælp, mens $\mathrm{fx}_{\mathrm{x}}$ Bangladesh med ca. det halve i bistand, var gledet markant tilbage blandt de danske prioritetslande (Danida 2009, 62 f.).

Afghanistan blev således det tydeligste eksempel på den sammentænkning af militære, sikkerhedspolitiske, udenrigspolitiske og udviklingspolitiske dimensioner, som for alvor slog igennem efter 2001, og som førte til en institutionalisering af civil-militære projekter og aktioner. Sådanne tilgange kom også i stigende grad til at kendetegne de udviklingspolitiske samarbejder, som Danmark etablerede i Afrika og resulterede i øvrigt i, at Løkke Rasmussen-regeringen $i$ forbindelse med forsvarsforliget fra 2010 etablerede en såkaldt Global Ramme, hvor der kunne trækkes på fælles midler fra forsvars, udenrigs- og udviklingsbudgetterne til civil-militære stabiliseringsopgaver. (Stepputat, Engberg-Pedersen \& Fejerskov 2012, 17 ff.).

Hvis de faldende bistandsbudgetter fra 2001 er den ene nye trend i den danske bistandspolitik, og den institutionelle indlejring af bistandspolitikken $\mathrm{i}$ en civilmilitær ramme er den anden, så er den tredje nye trend den øgede bilateralisering af den danske bistand. Hvor den multilaterale bistand i 2001 endnu lå på omkring $45 \%$ af den samlede bistand, var andelen i 2008 sunket til næsten 33\%. Det var ikke mindst FN-organisationer og programmer som fx UNDP, der fik beskåret sine bidrag, hvilket sammen de to øvrige nye tendenser understreger pointen, at den danske bistandsindsats ikke længere var rettet mod at understøtte en FN-baseret internationalisme, men snarere under bibeholdelse af nogle af de samme værdibaserede buzz-words var elementer i en international aktivistisk sikkerhedspolitik, hvis dominerende omdrejnings- og orienteringspunkt var og er USA. Derudover havde den øgede bilateralisering også det ra- 
tionale, at det var meget lettere at indtænke og tilgodese danske erhvervsinteresser i bilateral frem for multilateral bistand (Petersen 2010, 354 ff; Wivel 2013, 309 ff.; Brunbech \& Borring Olesen 2013, 108 ff.).

Samtidig må man imidlertid også slå fast, at en stor del af den danske bistand fortsat opererede inden for traditionens ramme med et stort fokus på fattigdomsbekæmpelse ikke mindst i Afrika. Fattigdomsbekæmpelse blev fastholdt som en bærende målsætning både i teori og praksis, ligesom Anders Fogh Rasmussen med inspiration fra et britisk initiativ søsat af Tony Blair i 2008 lancerede en Afrika Kommission med deltagelse af fremtrædende eksperter og politikere som Mozambiques statsminister Louisa Diogo og Tanzanias præsident Kikwete med den opgave at komme med forslag til, hvordan fattigdom kunne bekæmpes og udvikling, ikke mindst i den private sektor, kunne promoveres. Initiativet var Fogh Rasmussens eget og fulgte i kølvandet på, at Udenrigsministeriet efter et langt tilløb netop havde formuleret nye principper for den danske Afrika-politik. Det fik medierne til at spekulere i, om Fogh Rasmussens aktivisme på feltet måske også havde et rationale i en peronlige ambition om at profilere sig til en fremtidig international toppost (Information 21.4.2008; Brunbech \& Borring Olesen 2013, 110 f.).

Opsamlende kan man fastslå, at den danske bistandspolitik i det første tiår af det 21. århundrede var præget af både kontinuitet og brud. På den en side kørte en stor del af den danske bistand videre $i$ et traditionelt spor med fokus på fattigdomsbekæmpelse og med et prioriteret virkefelt i Afrika. På den anden side var perioden kendetegnet af en række nybrud, både når det gælder prioritering, orientering og profilering af bistanden. Vedr. prioriteringen springer det i øjnene, at bistandsprocenten begyndte at falde, hvilket som vist i en periode også ledte til direkte fald i de danske bistandsudbetalinger. I relation til en diskussion af bistandseffektivitet var faldet måske ikke afgørende, da der kan argumenteres for, at de høje bistandsbevillinger i 1990'erne ikke altid var ledsaget af tilstrækkelig sikring af, at pengene blev brugt hensigtsmæssigt. Men i et prioriterings - og profileringsperspektiv blev der sendt et signal om, at danske regeringer ikke længere tillagde bistandspolitikken samme vigtighed og ikke længerer lagde afgørende vægt på, at Danmark profilerede sig som bistandspolitisk 'front runner'.

Denne prioritering kan godt undre, når man medtænker et af de øvrige brud, nemlig tendensen til at lade bistandspolitikken indgå som et institutionaliseret element i den danske sikkerhedspolitik og som instrument til på den ene side at bekæmpe terrorisme og radikalisering og på den anden side at gøre bistanden til en integreret del af en dansk militær-civil indsats i Irak og Afghanistan. Dette var om noget højtprioriterede emner for Fogh Rasmussen regeringen, men altså ikke noget der første til en højere prioritering af bistandsfeltet.

Dette hænger måske delvis sammen med det tredje nybrud, den stigende afkobling af bistanden fra en traditionel dansk FN-baseret internationalisme. I hvert fald må man konstatere, at det især var den multilaterale bistand og ikke mindst bistanden til FN-systemets organisationer og hjælpeprogrammer, der måtte lægge ryg til nedskæringer. Bevægelsen var i og for sig også logisk nok, når forståelsen af bistanden var, at den måtte integreres intimt og organisk med de øvrige dele af udenrigs- og sikkerhedspolitikken. Her var der især efter 2001 som vist sket et skred væk fra en aktiv FN-baseret internationalisme til en international aktivisme med forholdet til USA som den centrale omdrejningsakse. Det påvirkede dansk udenrigspolitik på en række centrale områder, i forhold til EU-politikken, i forholdet til de andre nordiske lande, i forhold til FN og altså også i forhold til udviklings- og bistandspolitikken. Det centrale brud i den danske politik på sidstnævnte område ligger således på orienteringsplanet, selv om både prioriteringen og profileringen også blev ramt.

Spørgsmålet er, om der i Helle Thorning-Schmidts regeringsperiode 2011-15 skete modificeringer af dette billede. Her ved overgangen til en ny Lars Løkke Rasmussen-regering som konsekvens af valgresultatet $\mathrm{i}$ juni 2015 kan en forsøgsvis vurdering lægges frem. Aktivismen på feltet har i hvert fald været høj under ThorningSchmidt. I 2012 vedtog Folketinget en ny strategi for Danmarks udviklingssamarbejde, „Retten til bedre liv“ med fokus på fire kerneområder: menneskerettigheder og demokrati, grøn vækst, sociale fremskridt samt stabilitet og beskyttelse. Året efter i 2013 trådte en ny lov om Danmarks internationale udviklingssamarbejde så i kraft, som understreger, at formålet med dansk bistand er at bekæmpe fattigdom og fremme menneskerettigheder, demokrati, bæredygtig udvikling, fred og stabilitet i overensstemmelse med FN-pagten, Verdenserklæringen om Menneskerettighederne og FN's konventioner om menneskerettigheder, altså stort set de samme dimensioner som fremhæves i den nye strategi. Men loven præciserer også meget stærkere end den gamle lov fra 1971. at bistandspolitikken er et centralt og integreret element i den danske udenrigspolitik (Danida 2012; Lov om internationalt udviklingssamarbejde 2012).

Thorning-Schmidt-regeringen promoverede sig også gerne på, at den førte en aktivistisk udviklingspolitik, som ifølge udviklingsminister Mogens Jensen (S) burde have følgende ingredienser: en kritisk dialog med modtagerlande, hvor Danmark ikke viger tilbage for at præcisere sit værdipolitiske grundlag; danske virksomheder skal inddrages stærkere som partnere i bistanden og skal 
bidrage til promoveringen af danske værdier og dansk konkurrencekraft; bistanden skal bygges på folkelig forankring både i Danmark og i u-landene; Danmark skal opnå indflydelse gennem sit engagement og derfor satse på en høj profilering af sit bistandsengagement; danske humanitære organisationer understøttet af regering og offentlige bevillinger skal være stærke og effektive, når katastrofer rammer (Jensen 2014)

Ambitionen om at føre aktivistisk udviklingspolitik var der altså, men på den anden side indgik der ikke meget i prioriteringerne, der lægger op at se dem som understøttende en FN-baseret internationalisme. Der blev heller ikke øremærket mere multilateral hjælp til FN-systemet. Faktisk fik UNDP i 2014 stadigvæk ca. 100 mill. kr mindre i hjælp end i 2000, ligesom den samlede hjælp gennem FN-systemet var ca. 500 millioner lavere, end den var i 2000. I sit regeringsgrundlag lagde ThorningSchmidt-regeringen endvidere op til, at ODA-procenten igen skulle op på $1 \%$, men i praksis er den ikke kommet det, og bidraget ligger som under Lars Løkke Rasmussens første regering på omkring 0,85-0,87\% (Danida 2000, 166 f. og 2014).

Kigger man tilbage i historien er der altså ikke meget, der tyder på, at udviklings- og bistandspolitikken i perioden 2011-15 har afveget væsentligt fra det spor, der er nedlagt siden 2001. Derimod er det muligt, når man kigger frem, at man vil sige, at bistands- og udviklingspolitikken under Thorning-Schmidt trods alt havde en højere prioritering, end i perioden der fulgte efter. I hvert fald er der i regeringsgrundlaget for den nye Vmindretalsregering under Lars Løkke Rasmussen, som i juni 2015 er tiltrådt, indskrevet en målsætning om, at bistandsprocenten skal ned på $0,7 \%$ af BNI. Den danske bistandsprocent vil altså i de kommende år netop kun honorere FN's minimumsanbefaling og dermed relativt komme til at ligge på samme niveau som i slutningen af 1970'erne. Argumentationen er - stærkt tilskyndet af storbroder-støttepartiet Dansk Folkeparti - at pengene i stedet skal bruges til at finansiere national velfærd. I øvrigt signaleres den lavere prioritering af udviklingsbistanden også af, at den tiltrædende udenrigsminister Kristian Jensen skal dække hele den udenrigsministerielle ressort, idet udviklingsministerposten nedlægges (Politiken 2015; RitzauFokus 2015).

\section{Afslutning}

Dansk udviklings- og bistandspolitik har undergået en stor udvikling, men også transformation gennem de seneste godt 50 år. I perioden siden begyndelsen af 1960'erne har feltet udviklet sig til et centralt og i stigende grad prioriteret område i den danske udenrigspolitik. Prioriteringen kan aflæses af de fortsat øgede bevillinger frem til 2001, som fra 1978 placerede Danmark som et af de få lande, der levede op til FN’s 0,7\% ODA-målsætning, men også gjorde Danmark til 'overopfylder', der ved årtusindeskiftet var nået op på en årligt bistandsprocent på $1 \%$ - og det endda uden at medregne MIKA- og MIFRESTA-rammerne. Samtidig fik udviklingspolitikken med tiden både en mere selvstændig og mere integreret position inden for den overordnede udenrigspolitik. Det kom både til udtryk gennem områdets departementale position i Udenrigsministeriet og gennem Nyrup Rasmussen-regeringernes systematiske udpegning af en udviklingsminister til at administrere området.

Den øgede prioritering gik også hånd-i-hånd med en stærkere dansk profilering på feltet. K.B. Andersen brugte bistanden som et vigtigt element i hans og Anker Jørgensen-regeringernes højt-profilerede Afrika-diplomati i 1970'erne. Det samme var tilfældet under Nyrup Rasmussen-regeringerne i 1990'erne, som bragte bistanden i spil som redskab til at praktisere en „aktiv multilateralisme". Men selv i perioden efter 2001 blev feltet ind imellem trukket frem som et aktivt profileringsfelt, som det skete ved Anders Fogh Rasmussens Afrika-kommissionsinitiativ. Man skal heller ikke være blind for, at det høje bistandsengagement og profilering tog sig godt ud på renommé-kontoen og var med til at cementere billedet af Danmark - sammen med resten af Norden - som „,a humane internationalist". På trods af dette har den danske bistandspolitik ofte i praksis været noget mere sammensat og ikke kun været præget af høj profilering og engagement i forhold til den internationale udviklingsdagsorden. Eksemplet med Den $\mathrm{Ny} \varnothing$ konomisk Verdensorden i 1970'erne er et godt eksempel, hvor danske regeringer tog få initiativer og holdt lav profil for ikke at lægge for stor afstand hverken til udviklingslandene eller til USA's og EF’s dagsorden på spørgsmålet.

Hovedårsagen til, at den danske bistandspolitik trods alt i stigende grad fremstod som både højt prioriteret og højt profileret var, at bistand blev et redskab, som understøttede væsentlige orienteringer i den danske udenrigspolitik. For det første var bistandspolitik et velegnet virkefelt for skabelsen af en global tilstedeværelse for Danmark - noget som med afkolonialiseringen fremstod som stadig vigtigere. For det andet - og ikke uden forbindelse med argumentet overfor - blev bistand en del af den politiske burden-sharing, som USA forsøgte at promovere i den kolde krig, og hvor mange danske politikere nok hellere lagde et helhjertet engagement $i$ bistanden, end de gjorde inden for den militære burdensharing. For det tredje kom bistanden til at understøtte FN-hjørnestenen og dermed FN-internationalismen. Bistand blev på denne måde en strategisk satsning inden for den idealistiske langtidsmålsætning for dansk uden- 
rigspolitik, der sigtede mod at skabe en retsbaseret og social retfærdig verdensorden. Alt dette trak i retning af at prioritere og profilere bistandssatsningen, men den kolde krig og den kompartmentaliserede opdeling af udenrigspolitikken betød samtidig, at potentialet måske ikke altid blev udnyttet fuldt ud, eller at der opstod selvmodsigelser i bistandspolitikken, når den både skulle imødekomme realpolitiske og mere idealpolitiske hensyn.

Denne modsætning blev imidlertid ophævet med afslutningen af den kolde krig. Med elimineringen af den bipolære systemkonflikt og herunder også den territorielle trussel mod Danmarks sikkerhed greb Schlüter- og Nyrup Rasmussen-regeringerne ‘øjeblikkets medvind' til at lade dansk udenrigspolitik understøtte en internationalistisk dagsorden med ønsket om en FN-baseret retsorden præget af respekt for menneskerettighederne, god regeringsførelse og en retfærdig og bæredygtig økonomisk udvikling. I en sådan ramme kunne kompartmentaliseringen af udenrigspolitikken også ophæves, idet såvel de sikkerhedspolitiske (militære) som mere generelle udenrigspolitiske dimensioner kunne flyde sammen til en fælles understøttelse af en aktiv internationalistisk udenrigspolitik. Dette forklarer også, hvorfor bistandspolitikken i 1990'erne blev så højt prioriteret og profileret, men også hvorfor den blev meget tættere integreret med den øvrige udenrigspolitik såvel organisatorisk som politisk.

Med Fogh Rasmussen-regeringens tiltræden i 2001 vendte bistandsvinden. Bevillingerne blev beskåret, og den danske bistand fik noget af et Janus-ansigt. På den ene side levede en del af bistanden videre i 1990'ernes spor med fokus på fattigdomsbekæmpelse og bistand til de fattigste lande i Afrika. På den anden side blev bistanden mere bilateraliseret og mere afstemt efter Danmarks sikkerhedspolitiske prioriteringer med en samtænkning og institutionalisering af civile og militære indsatser, klarest markeret gennem brugen af både bistandsarbejdere og kamptropper i Afghanistan.

Faldet i den multilaterale del af bistanden er det tredje, men ikke mindst symbolske brud med bistandsprioriteringen og orienteringen fra før 2001. Sammen med den højere prioritering af bistand til sikkerhedspolitiske formål (terrorbekæmpelse, anti-radikalisering, flygtninge og flygtningestrømme og sikkerhedsstabilisering) er afskeden med den aktive multilateralisme en stærk indikator for, at en traditionel national forståelse snarere end internationalistiske forståelse i dag er den primære dynamo bag tilrettelæggelsen af bistandspolitikken. Det synes også grundlæggende at være bekræftet med det program og den prioritering af den fremtidige udviklingsbistand, som den nye Løkke Rasmussen regering er tiltrådt med i sommeren 2015. Det gør ikke nødvendigvis politikken mindre aktivistisk, men det er oplagt, at den finder sit raison d'etre et helt andet sted, end det traditionelt var tilfældet under de første 40 år af bistandshistorien.

I den forstand er det ikke en urimelig konklusion, at der sket et delvist paradigmeskift i den danske bistandspolitik - et paradigmeskift, der både har rødder i en dansk nationalpolitisk kontekst, men også i det faktum, at verden har forandret sig, herunder ikke mindst at $\mathrm{FN}$ i dag næppe udgør det internationalistiske pejlemærke, det gjorde for 20 år siden.

\section{Litteraturliste}

Andersen, K.B. 1983, I alle de riger og lande ... . Oplevelser i 70'ernes danske udenrigspolitik, Gyldendal, København.

Borring Olesen, T. 2008a, „Stabilitet og turbulens: Udviklingspolitikken 1975-1989“, i C. Friis Bach, T. Borring Olesen, S. KaurPedersen \& J. Pedersen, Idealer og realiteter. Dansk udviklingspolitiks historie 1945-2005, 258-389, Gyldendal, København.

Borring Olesen, T 2008b, „Between Words and Deeds. Denmark and the NIEO agenda 1974-1982“, i H. Pharo \& M. Pohle Fraser (eds), The Aid Rush, Aid Regimes in Northern Europe during the Cold War, Issues in Contemporary Politics, Unipubl., Oslo, vol. I 145-182.

Borring Olesen, T, Pharo, H. \& Paaskesen K. 2013, „Conclusion. Aid Norms, foreign Policy and the Domestic Context“, i T. Borring Olesen, H. Pharo \& K. Paaskesen (eds.): Saints and Sinners. Official Development Aid and Its Dynamics in a Historical and Comparative Perspective, s. 329-365, Akademika Publ, Oslo.

Borring Olesen, T. \& Villaume, P. 2005, „I blokopdelingens tegn $1945-$ 1972“, Dansk Udenrigspolitiks Historie, vol. 5, Danmarks Nationalleksikon/Gyldendal, København.

Branner, H. 2000, „The Danish Foreign Policy Tradition in a European Context“, i H. Branner \& M. Kelstrup (eds.), Denmark's Policy towards Europe after 1945. History, Theory and Options, Syddansk Universitetsforlag, Odense, s.. 185-220.

Brunbech, P.Y. 2006, Dansk udviklingspolitik 1949-1971. En analyse af den tidlige udviklings- og bistandspolitik over for ulandene og dens funktion $i$ dansk udenrigspolitik, upubl ph.d.-afhandling, Aarhus Universitet.

Brunbech, P.Y. \& Borring Olesen, T. 2013, „The Late Front Runner: Denmark and the ODA Percentage Question, 1960-2008“, i T.B. Olesen, H. Pharo \& K. Paaskesen (eds.): Saints and Sinners. Official Development Aid and Its Dynamics in a Historical and Comparative Perspective, s. 89-121, Akademika Publ, Oslo.

Brun Pedersen, R. \& Gram-Skjoldager, K. 2015, „International aktivisme i dansk udenrigspolitik 2001-2009. En tværfaglig forskningsstatus“, Historisk Tidsskrift, nr. 115(1) (under udgivelse).

Bøgh, N. 2003, Hakkerup, Aschehoug, København.

Danida 1991, Danmarks deltagelse $i$ det internationale udviklingssamarbejde, Udenrigsministeriet, København.

Danida 1994, En verden i udvikling. Strategi for dansk udviklingspolitik frem mod ar 2000, København.

Danida 2000, Danidas årsberetning 2000, København.

Danida 2003, En verden til forskel. Regeringens bud på nye prioriteter for dansk udviklingsbistand 2004-2008, København.

Danida 2009, Danmarks deltagelse $i$ det internationale udviklingssamarbejde. København

Danida 2012, Retten til et bedre liv. Strategi for Danmarks udviklingssamarbejde, København. 
Danida 2014, „Bistandskronen 2014“, download fra: http://openaid. um.dk/da/oda/?Y=2014 (tilgået 23.4.2015)

Due-Nielsen, C. \& Petersen, N. 1995, „Denmark's Foreign Policy since 1967: An Introduction“, i C. Due-Nielsen og N. Petersen (ed.), Adaptation \& Activism. The Foreign Policy of Denmark, DJøF Forlag, København.

Engberg-Pedersen, L. 2007; „Dansk indenrigspolitik, Paris-erklæringen og udvikling - en harmonisk relation?", Den Ny Verden, vol. 40(3), s. $45-56$.

Holm, H.-H. 1982, Hvad Danmark gør... .En analyse af dansk u-landspolitik, Politica, Aarhus.

Hækkerup, P. 1965, Danmarks udenrigspolitik, Fremad, København.

Information 2008, „Afrika-kommissionen“ (Peter Thygesen) 21.4., fra http://www.information.dk/158142 (tilgået 23.4.2015)

Jensen, M. 2014, ,Fem veje til en aktivistisk udenrigspolitik“, Berlingske (kronik), 19.8.2014

Jørgensen, K. 1977, Hjalp fra Danmark. En studie i dansk u-landspolitik 1960-1971, Odense Universitetsforlag, Odense.

Kelm-Hansen, C. 2000, Det koster at vare solidarisk. Socialdemokratisk u-landspolitik 1945-2000, Fremad, København.

Krag, J.O. 1959, håndskrevne talepunkter til tale i Venstres Ungdom 16.2.1959, JOK’s arkiv, ABA København, kasse 59.

Lancaster, C 2007, Foreign Aid. Diplomacy, Development, Domestic Politics, The University of Chicago Press, Chicago.

Lov om Internationalt udviklingssamarbejde 2012. Download fra: https://www.retsinformation.dk/forms/R0710.aspx?id=142451 (tilgået 23.4.2015)

Midtgaard, K 2005, Småstat, magt og sikkerhed. Danmark og FN 19491965, Syddansk Universistesforlag, Odense 2005).

Midtgaard, K. 2009, „Nordic cooperation in the United Nations during the First Cold War: between internationalism and realpolitik, i N. Götz \& H. Haggrén (eds.), Regional Cooperation and International
Organizations. The Nordic model in transnational alignment, Routledge, London, s. 47-64.

OECD.StatExtracts: total flows by donor (ODA\%GNI) at, http://stats. oecd.org/Index.aspx?DatasetCode=TABLE1\#

Olsen, G.R. 2005, 'Danish Aid Policy in the Post-Cold War Period: Increasing Resources and Minor Adjustments', in: P. Hoebink and O. Stokke (eds.), Perspectives on European Development Co-operation: Policy and performance of individual donor countries and the $E U$, Routledge, Abingdon, pp. 184-214.

Pedersen, J 2008, „Det bilaterale program i støbeskeen 1962-1975“, i C. Friis Bach, T. Borring Olesen, S. Kaur-Pedersen \& J. Pedersen, Idealer og realiteter. Dansk udviklingspolitiks historie 1945-2005, 116-257, Gyldendal, København.

Petersen, N. 2006, „Europæisk og globalt engagement 1973-2006“, Dansk Udenrigspolitiks Historie, vol. 6, Gyldendal 2. udg., København.

Petersen, N. 2010, „Hinsides den kolde krig: Danmarks internationale ordenspolitik 1990-2009“, i C. Due-Nielsen, R. Mariager g R. Schmidt (red.), Nye fronter i den kolde krig, Gyldendal, København, 339-360.

Politiken 2015, „Regeringsgrundlag: Lavere skat og bistand“, 29.06.2015.

Riddell, R.C. 2007, Does Foreign Aid Really Work? Oxford University Press, Oxford.

RitzauFokus 2015, „Udenrigsministeren vil spare og løfte Afrika“, 20.06.2015.

Stepputat, A., Engberg-Pedersen, L. \& Fejerskov, A.M. 2012, „Dansk bistand som sikkerhedspolitisk instrument, 1992-2009“, DIIS Report, 2012:01, København.

Wivel, A. 2013, „From Peacemaker to Warmonger? Explaining Denmark's Great Power Politics, i Swiss Political Science Review, 19(3), 298-321. 